\title{
Preparation and characterization of composites from plastic waste and sugar cane fiber
}

\author{
Ricardo Yoshimitsu Miyahara1*, Fábio Luiz Melquiades², Ezequiel Ligowski ${ }^{3}$, Andressa do Santos ${ }^{4}$, \\ Silvia Luciana Fávaro ${ }^{5}$ and 0 smar dos Reis Antunes Junior ${ }^{3}$
}
${ }^{1}$ Departamento de Física, Universidade Estadual do Centro-Oeste - UNICENTRO, Guarapuava, PR, Brazil ${ }^{2}$ Departamento de Física, Universidade Estadual de Londrina - UEL, Londrina, PR, Brazil
${ }^{3}$ Departamento de Química, Universidade Estadual do Centro-Oeste - UNICENTRO, Guarapuava, PR, Brazil

${ }^{4}$ Departamento de Química, Universidade Estadual de Maringá - UEM, Maringá, PR, Brazil

${ }^{5}$ Departamento de Engenharia Mecânica, Universidade Estadual de Maringá - UEM, Maringá, PR, Brazil

*rmiyahara@unicentro.br

\begin{abstract}
This study presents the preparation and characterization of composite materials using Plastic Waste from Hydrapulper (PWH) from paper industries extruded with sugar cane fiber residues from ethanol industries. The factorial design showed that composite material with $40 \%$ of sugar cane fiber, pressed with 5 ton was the optimized condition. The main findings attested that the composite is resistant up to $250^{\circ} \mathrm{C}$ and its hardness is increased compared to the raw PWH. The material presented woodsy aspect although water absorption has increased. So, this study offers a good alternative for the use of plastic waste generated as a by-product of recycled paper industry as well as a destination to the sugar cane bagasse.
\end{abstract}

Keywords: cane bagasse fiber, composite material, hidrapulper equipment, plastic waste, alternative material for wood.

\section{Introduction}

The multiple application possibilities of plastic materials, stimulated by the diversity of its properties and characteristics have been conducted to its frequent use in several applications, including civil engineering. The high cost of metals and cement for the production of reinforced concrete and the lack of wood allied to the large amount of plastic material available for recycling increased the use of thermoplastic composites. The use of materials which are able to combine basic requirements, such as the conservation of natural resources and the environment preservation, can be essential for the future of the planet. Considering these problems, a challenge is the production of environmental friendly materials or perform the correct destination and reutilization of plastic materials ${ }^{[1,2]}$. The transformation process of plastic waste in composites materials is a viable option to stimulate practices that prioritizes recycling and development of new materials through the utilization of environmental liabilities.

A polymeric composite is formed by two phases: a continuous one, that is a thermoplastic base matrix and the dispersive phase, which are reinforcing fillers of organic or inorganic fibers ${ }^{[3]}$. The incorporation of fiber have been widely investigated and used as reinforcement in polymer matrices such as sponge gourd fiber ${ }^{[4]}$, sisa ${ }^{[5]}$, curauá ${ }^{[5]}$, sugar beet pulp ${ }^{[6]}$ and sugarcane bagasse fiber ${ }^{[7]}$. Acacia bark residues was used as reinforcing filler in polypropylene composite can produce higher impact properties and higher degradation temperature ${ }^{[8]}$. Taflick et al. ${ }^{[8]}$ atributed this behavior to the of tiny and short fibers due distributed more homogeneously of composite. Researchers done by Martins et al. ${ }^{[9]}$ and
Rzatki and Barra ${ }^{[10]}$ proved the effectiveness of the natural amorphous silicate short fibers as reinforcing agents increasing the tensile strength of reinforcement matrix of the epoxy and poly (butylene terephthalate), respectively. The final product will be a polymeric and natural fiber composite as an alternative or replacement to wood and its derivatives, reducing deforestation and pollution.

The residues from the Hydrapulper machinery represent high destination costs both financially and environmentally. The technological equipment, Hydrapulper, is used at the separation of polymer residues, plant fibers and additives coming from containers of the recycled paper industry. This machinery is similar to a giant blender with a pond in cylinder form. The procedure is performed adding water to the paper that will be recycled and by a physical agitation process, the paper fibers are detached forming a cellulose pulp. These fibers are washed and purified, being used for the production of paper in the form of cardboard boxes, napkins, and other products. In a sieve located below the spinning rotor, the impurities in the process, such as various plastics, non disaggregated fibers and small quantities of metals that are retained originating the Plastic Waste from Hydrapulper (PWH), which is a very difficult waste to be recycled and is commonly sent to specific landfills causing concern with the disposal and vast environmental problems.

On the other hand, the abundance of natural fibers such as sisal, coconut, jute, ramie bast, eucalyptus pulp, banana, hemp, flax, pineapple leaf, bamboo, palm, cotton, waste of 
mate-tea and sugarcane fiber among others and the possibility of using these fibers as reinforcement in composites stimulate the studies of different products combining these raw materials ${ }^{[1-15]}$. Each of these natural fibers has a wide range of mechanical and physical properties governing its wider applications. They are renewable, biodegradable, non-toxic, non-abrasive, they have low density with specific strength and low cost. Moreover, they are available worldwide been characterized as "environmentally-friendly" materials ${ }^{[16-18]}$.

Sugarcane bagasse is the by-product obtained after sucrose extraction from the sugar cane plant or ethanol fuel plant. It is especially interesting because it is considered the main residue from Brazilian agro industry, which generates around $270 \mathrm{~kg}$ of bagasse per ton of cane ground with an annual accumulation of 132 million tons. They are used in industrial furnace and for second generation ethanol, organic fertilizing, animal feed and cellulose and paper production. Sugarcane fibers are composed of cellulose, hemicelluloses and lignin as well as small amounts of mineral, wax, and other compounds ${ }^{[19,20]}$.

The objective of this study was to prepare and characterize composite materials using $\mathrm{PWH}$ from paper industries extruded with sugar cane fiber (SCF) residues from ethanol industries. In Specific (a) a factorial design has been conducted to optimize the proportions and compaction pressure in the composite preparation and (b) characterization tests consisting of physical, chemical and mechanical tests, thermal stability and morphology of the composites materials.

\section{Materials and Methods}

\subsection{Raw materials and composite}

The PWH was obtained from a paper recycling factory from Guarapuava, PR, Brazil. The material showed moisture content $\sim 50 \%$ and was first centrifuged and then dried in an oven at $100^{\circ} \mathrm{C}$. Clamps, clips, wires, nails and other metallic residues were magnetically separated by a device adapted in the entrance of a Wiley knife mill. In the sequence the plastic waste was bonded for 5 minutes in a thermo-kinetic mixer. Finally the material was cut into small particles using the same mill with a 30 mesh sieve (Figure 1a-c).

Sugar cane fibers were collected from a sugar and ethanol plant in São Pedro do Ivaí, PR, Brazil. The material was dried in an oven at $100{ }^{\circ} \mathrm{C}$ and milled in Wiley knife mill with 30 mesh sieve (Figure 1d).

\subsection{Preparation of the composites}

The PWH and sugar cane particles were mixed and homogenized at $120 \mathrm{rpm}$ for 5 minutes at room temperature using a thermo-kinetic mixer. The proportions of fiber and polymer contents were performed according to the factorial design that is presented in section 2.4.

For the processing of PWH and the formulated composites, a laboratory single-screw extruder with $45 \mathrm{~mm}$ cannon by $300 \mathrm{~mm}$ in length and a screw with $25 \mathrm{~mm}$ of diameter by $350 \mathrm{~mm}$ in length was used, Tornoeste brand (model ET 001).
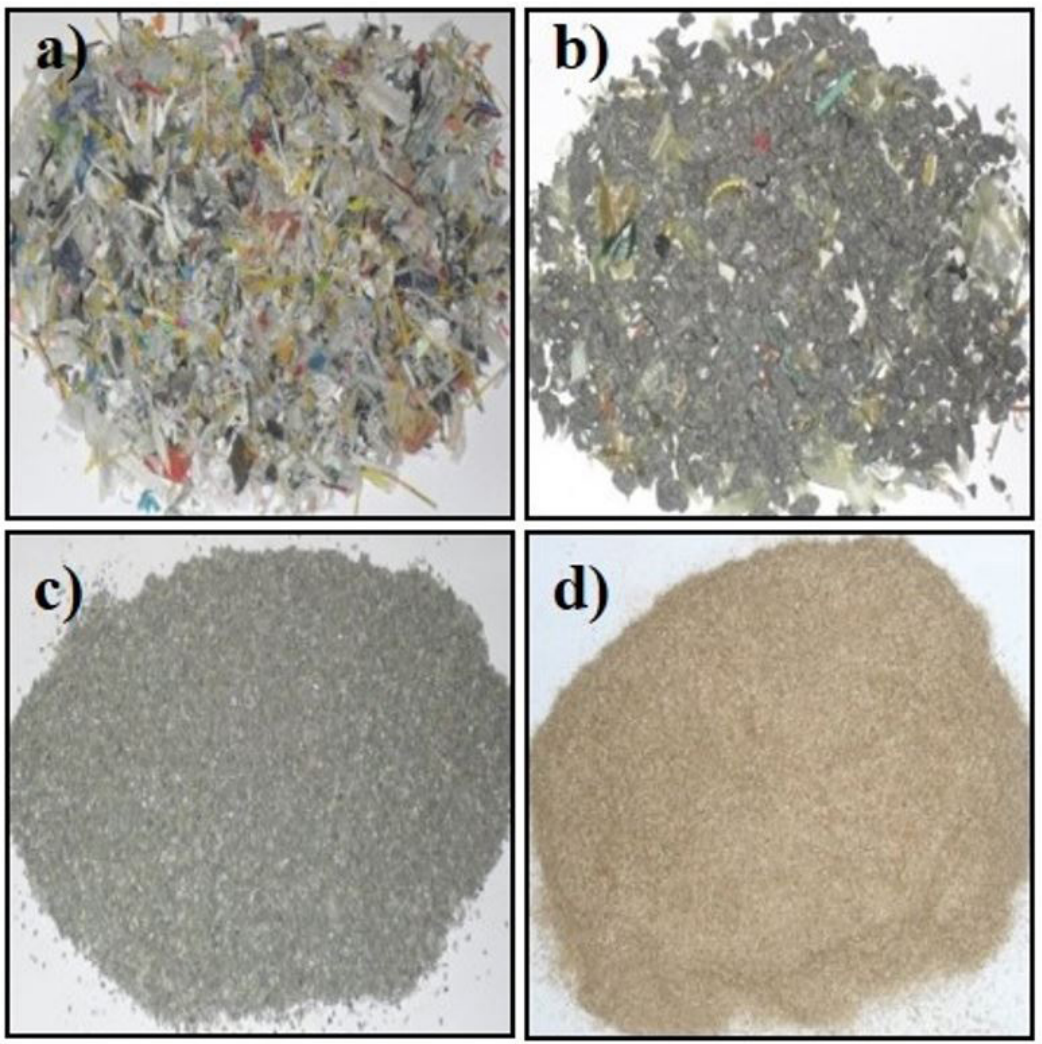

Figure 1. (a) PWH after first milling and removal of metals. (b) PWH after agglutination process (c) PWH after micronization. (d) Particles of Sugar cane fiber. 
A rotation process of $100 \mathrm{rpm}$ and four heating temperatures were employed, respectively: $160 \pm 5^{\circ} \mathrm{C}$ (power zone), $175 \pm 5{ }^{\circ} \mathrm{C}$ (compression zone), $190 \pm 5{ }^{\circ} \mathrm{C}$ (dosage) and $200 \pm 5^{\circ} \mathrm{C}$ on the coupling head.

It was possible to check the viscosity and fluidity of plastic waste and the polymeric composites, proposed by the factorial design, by the pressure of extruded paste, evaluated on the pressure gauge of the extruder.

After the extrusion process, the composites were molded for the mechanical testes according to ISO and ASTM standards. The samples were pressed with 10 or 5 tons for $90 \mathrm{~s}$, according to the factorial design (section 2.4). Additives or coupling agents were not used in the molding process.

\subsection{Thermal analysis}

Thermal analyses have been performed to analyze the thermal behavior of the raw PWH, the raw sugarcane fiber and the composite material. Tests were done with a equipment SDT Q600 from TA Instruments. Thermogravimetry (TG) and differential scanning calorimetry (DSC) have been applied to determine the weight gain, the mass loss rate and the degradation process. Five milligrams of each samples have been analyzed at the temperature range from $20^{\circ} \mathrm{C}$ to $1000{ }^{\circ} \mathrm{C}$ at a heating rate of $10{ }^{\circ} \mathrm{C} \cdot \mathrm{min}^{-1}$ in a nitrogen flow of $100 \mathrm{~mL} \cdot \mathrm{min}^{-1}$.

\subsection{Factorial design}

A $2^{2}$ factorial design was performed with the purpose to optimize the production conditions of the polymeric composite $^{[21]}$, considering fiber proportions and compaction pressure. Initially, one sample of each of the following charge content (sugar cane fiber) has been prepared: $20 \%, 30 \%, 40 \%$ and $50 \%$. The factorial design was performed considering $30 \%$ and $40 \%$ because with $50 \%$ the extrusion process is very hard and the material has low hardness. With $20 \%$ of fiber content the material loses its wood appearance. The compaction factor was evaluated to analyze if differences in the pressure eliminates some empty spaces in the interfacial region of the materials which interfere in moisture and mechanical hardness of the samples. The studied values were 10 and 5 ton. Table 1 present the factorial design experiment. Five samples of each condition were prepared and evaluated for tensile strength, impact, hardness, moisture modifications and composite density.

\subsection{Physical and mechanical tests}

Water absorption was carried out according to ASTM D-1037 with $24 \mathrm{~h}$ immersion time in a thermostatic batch at $20^{\circ} \mathrm{C}$. The body tests were weighed before and

Table 1. Factorial design description.

\begin{tabular}{ccc}
\hline Essay & $\begin{array}{c}\text { Factor 1 } \\
\text { (proportion) }\end{array}$ & $\begin{array}{c}\text { Factor 2 } \\
\text { (compaction) }\end{array}$ \\
\hline 1 & $70 \% \mathrm{PWH} / 30 \%$ bagasse fiber $(-)$ & 5 ton $(-)$ \\
2 & $60 \% \mathrm{PWH} / 40 \%$ bagasse fiber $(+)$ & 5 ton $(-)$ \\
3 & $70 \% \mathrm{PWH} / 30 \%$ bagasse fiber $(-)$ & 10 ton $(+)$ \\
4 & $60 \% \mathrm{PWH} / 40 \%$ bagasse fiber $(+)$ & 10 ton $(+)$ \\
\hline
\end{tabular}

$\mathrm{PWH}$ - plastic waste from hydrapulper. after the immersions. Water absorption was determined using Equation 1:

$$
\% \text { moisture }=\frac{\text { wet sample mass }- \text { dry sample mass } \times 100}{\text { dry sample mass }}
$$

The density of the composites and of the raw PWH was carried out with a Multipycnometer from Quantachrome Insruments using He gas. The measurements were performed in triplicate.

The mechanical properties of the raw PWH and of the composites were evaluated through tensile strength at break (ASTM D-638) in an EMIC DL 10000 machine, flexural strength (ASTM D-790) in an LLOYD LR10K, Impact strength (Izod) with V notch (ASTM D-256) at room temperature in a RESIL impactor 5R, compression strength (ISO 604) in a EMIC DL 30000 and hardness shore (ABNT 7456) with a WOLTEST GSD 702D. All mechanical properties were determined using at least 5 samples for each test.

\subsection{Morphological analysis}

Analysis of fracturated surfaces from raw $\mathrm{PWH}$ and from polymeric compounds obtained from Izod Impact test were performed by SEM using a TM300 Hitachi microscope. The samples were fixed in a carbon tape prior to analysis.

The PWH and sugar cane particles were mixed and homogenized at $120 \mathrm{rpm}$ for 5 minutes at room temperature using a thermo-kinetic mixer. The proportions of fiber and polymer contents were performed according to the factorial design that is presented in section 2.4.

For the processing of PWH and the formulated composites, a laboratory single-screw extruder with $45 \mathrm{~mm}$ cannon by $300 \mathrm{~mm}$ in length and a screw with $25 \mathrm{~mm}$ of diameter by $350 \mathrm{~mm}$ in length was used, Tornoeste brand (model ET 001). A rotation process of $100 \mathrm{rpm}$ and four heating temperatures were employed, respectively: $160 \pm 5{ }^{\circ} \mathrm{C}$ (power zone), $175 \pm 5^{\circ} \mathrm{C}$ (compression zone), $190 \pm 5^{\circ} \mathrm{C}$ (dosage) and $200 \pm 5^{\circ} \mathrm{C}$ on the coupling head.

It was possible to check the viscosity and fluidity of plastic waste and the polymeric composites, proposed by the factorial design, by the pressure of extruded paste, evaluated on the pressure gauge of the extruder.

After the extrusion process, the composites were molded for the mechanical testes according to ISO and ASTM standards. The samples were pressed with 10 or 5 tons for $90 \mathrm{~s}$, according to the factorial design (section 2.4). Additives or coupling agents were not used in the molding process.

\section{Results and Discussions}

\section{1 Thermal analysis}

Figure 2 presents the thermograms for raw fiber, raw PWH and composites with $30 \%$ and $40 \%$ of fiber charge. It was observed that all these materials keep stable up to $250{ }^{\circ} \mathrm{C}$ eliminating retained moisture. It demonstrates that these raw materials are apt for extrusion, injection and thermoforming process, since $200 \pm 5^{\circ} \mathrm{C}$ was the maximum temperature applied in the composites preparation.

The curves for raw PWH show mass loss and small degradation in the $250{ }^{\circ} \mathrm{C}$ to $450{ }^{\circ} \mathrm{C}$ interval. In the end of 
the composition process, the residual mass is smaller than in the polymeric composites.

Between $250{ }^{\circ} \mathrm{C}$ and $450{ }^{\circ} \mathrm{C}$ the composite with $40 \%$ fiber loses less mass and degrades more slowly than the sample with 30\% fiber. It is in agreement with the literature which shows that natural fiber compounds have higher heat resistance and consequently high resistance to decomposition. So, cellulose and lignin contribute to the thermal resistance of the polymeric composite with higher fiber charge ${ }^{[22]}$. For temperatures over $450{ }^{\circ} \mathrm{C}$ the mass loss is equivalent.

Endothermic crystalline transitions are evidenced by DSC curves, Figure 3. For temperatures below $120^{\circ} \mathrm{C}$ second order transitions are present, demonstrating the presence in smaller quantities of amorphous polymers (PS, ABS, PVC). Over $200{ }^{\circ} \mathrm{C}$ the discontinuities occur due to the presence of semi-crystalline high fusion polymers (PET, PA 6/6.6, PC) $)^{[23,24]}$. The main events are polyolefin fusion (polyethylene and polypropylene) at $125.6{ }^{\circ} \mathrm{C}$ and $160.8^{\circ} \mathrm{C}$, besides the onset thermal degradation at $266.5^{\circ} \mathrm{C}$ and offset at $465.9^{\circ} \mathrm{C}$, demonstrated in heat absorption peaks. As for sugar cane bagasse fibers, an endothermic peak was observed at $66.6^{\circ} \mathrm{C}$ related to the moisture loss. The peaks at $300.3{ }^{\circ} \mathrm{C}$ (endothermic) and $355.3^{\circ} \mathrm{C}$ (exothermic) represent hemicelluloses and cellulose degradation, respectively. Lignin degradation occurs at $395^{\circ} \mathrm{C}$ as shown by the exothermic peak ${ }^{[25,26]}$.

\subsection{Physical and mechanical properties}

Incorporated as polymeric matrix in composites, the purpose is to use PWH to replace raw polymers like polyolefin that are the most used thermoplastics. Table 2 presents the results of physical and mechanical properties of the raw PWH and also compares it with the main polymers commonly used to prepare composites.

The PWH absorbs higher water quantity when compared to polyethylene and polypropylene because in this plastic waste there is an incorporation of small quantities of cellulose residues in the plastic surface. The presence of these fibers and other impurities increases water retention. The PWH is denser than the polyolefin due to smaller proportion of thermoplastics, thermosets and elastomers which enlarge the final density.

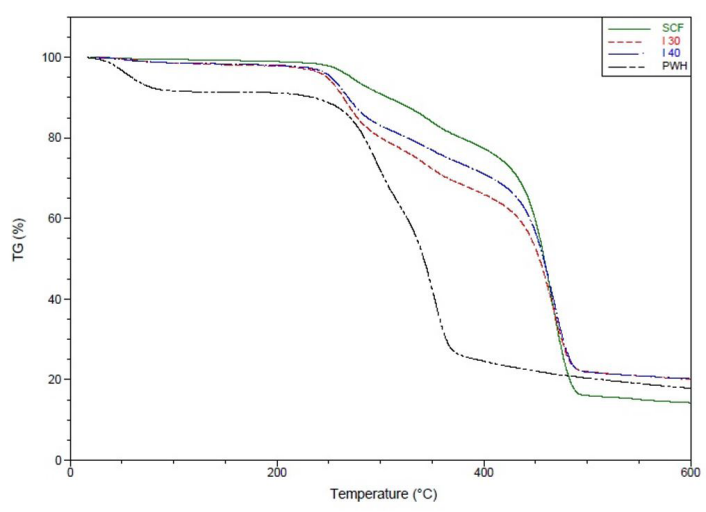

Figure 2. Thermograms (TG) curves for sugar cane fiber (SCF), and polymeric composites with $30 \%$ (I 30) and 40\% (I 40) fiber charge, and pure plastic waste from hydrapulper $(\mathrm{PWH})$.

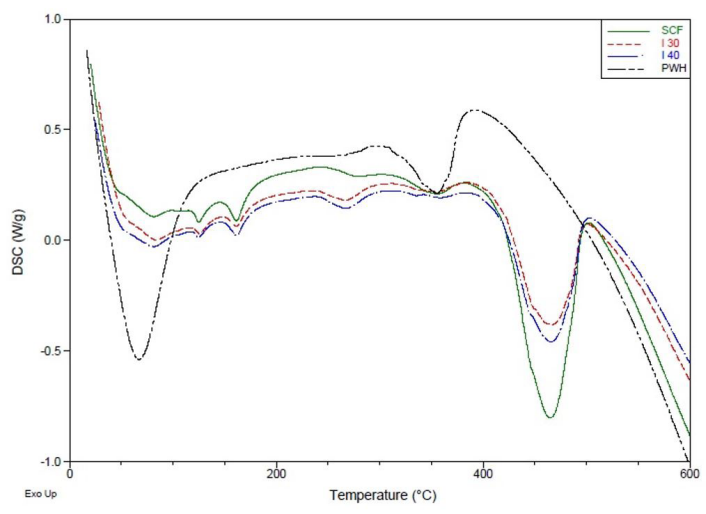

Figure 3. Differential Scanning Calorimety (DSC) curves for sugar cane fiber (SCF), polymeric composites with 30\% (I 30) and 40\% (I 40) fiber charge, and pure plastic waste from hydrapulper (PWH).

Table 2. Mechanical and physical properties of PWH compared to virgin and recycled polymers.

\begin{tabular}{|c|c|c|c|c|c|c|}
\hline $\begin{array}{l}\text { Polymeric } \\
\text { Matrix }\end{array}$ & $\begin{array}{c}\text { Hardness Shore D } \\
\text { (0 to 100) }\end{array}$ & $\begin{array}{l}\text { Flexural } \\
\text { strength }\end{array}$ & $\begin{array}{l}\text { Tensile } \\
\text { strength }\end{array}$ & $\begin{array}{c}\text { Izod impact } \\
\text { strength } \\
(\mathrm{J} / \mathrm{m})\end{array}$ & $\begin{array}{c}\text { Moisture } \\
\text { absorption (\%) }\end{array}$ & $\begin{array}{l}\text { Density } \\
\left(\mathrm{g} \mathrm{cm}^{-3}\right)\end{array}$ \\
\hline PWH & $41.4 \pm 0.7$ & $18.6 \pm 0.3$ & $9.6 \pm 0.4$ & $73.9 \pm 2.0$ & $0.95 \pm 0.06$ & $1.00 \pm 0.06$ \\
\hline PEHD & $62.0 \pm 0.79^{[27]}$ & $18.99 \pm 0.45^{[27]}$ & $20.73 \pm 0.44^{[27]}$ & ------------ & $<0.01^{[28,29]}$ & $0.94-0.98^{[28,29]}$ \\
\hline \multirow{2}{*}{ Recycled } & ------------ & $\cong 20.5^{[2]}$ & $\cong 21.0^{[2]}$ & $\cong 46.5^{[2]}$ & & \\
\hline & $64.0^{[30]}$ & $24.87^{[30]}$ & $25.66^{[30]}$ & $33.9^{[30]}$ & & \\
\hline PEHD & $62.9 \pm 0.55^{[27]}$ & ----------- & $24.53 \pm 0.12^{[27]}$ & ----------- & & \\
\hline \multirow[t]{2}{*}{ Virgin } & $65.0^{[30]}$ & $24.87^{[28]}$ & $24.73^{[30]}$ & $38.34^{[30]}$ & & \\
\hline & ----------- & $19.76 \pm 0.39^{[31]}$ & $18.9 \pm 0.2^{[31]}$ & ----------- & & \\
\hline $\mathrm{PP}$ & $68.2 \pm 0.57^{[27]}$ & $41.74 \pm 0.49^{[27]}$ & $28.96 \pm 0.67^{[27]}$ & ------------ & & \\
\hline \multirow[t]{2}{*}{ Recycled } & ----------- & ------------ & $22.78 \pm 1.14^{[32]}$ & $26.25 \pm 4.5^{[32]}$ & & \\
\hline & ----------- & $18.2^{[33]}$ & $16.1^{[33]}$ & ------------- & & \\
\hline $\mathrm{PP}$ & $71.0 \pm 0.71^{[27]}$ & $43.48 \pm 0.51^{[27]}$ & $30.72 \pm 0.45^{[27]}$ & ----------- & $<0.03^{[34,35]}$ & $0.90-0.91^{[29,35]}$ \\
\hline \multirow[t]{3}{*}{ Virgin } & ---------- & ------------- & $37.36 \pm 1.87^{[33]}$ & $25.05 \pm 1.6^{[33]}$ & & \\
\hline & & $55.74^{[36]}$ & $34.11^{[36]}$ & $5.68^{[36]}$ & & \\
\hline & ----------- & ------------ & $23.4 \pm 1.3^{[37]}$ & $8.5^{[37]}$ & & \\
\hline
\end{tabular}

$\mathrm{PWH}=$ Plastic waste from hydrapulper; $\mathrm{PEHD}=$ polyethylene high-density; $\mathrm{PP}=$ Polypropylen. 
Shore D hardness and tensile strength presents smaller values in the PWH compared to the other polymers. For flexural strength the values were similar to virgin or recycled PEAD. As mentioned before, the $\mathrm{PWH}$ is composed by a mix of thermoplastics, thermosets and elastomers that are melted to form the polymeric matrix. But the polymers that have high melting temperatures are incorporated to the composite as particulate charge generating micrometric empty spaces between the particulate and the polymeric matrix. This fact restricts the mechanical properties that require higher interface adhesion of the materials as noted in the tensile strength test.

In the Izod impact test is possible to verify that the PWH has greater resistance compared to the polyolefin. So the composite could be employed in applications that require high impact resistance.

Factorial design results and the comparison among the raw PWH and the composites are presented in Table 3. When shore hardness is analyzed, it is possible to verify that with 5 ton the results are equivalent in both proportions, but with 10 ton and $40 \%$ fiber the shore hardness decreased. For tensile strength all the results are equivalent considering the standard deviation with a slightly decrease for higher pressure quantities. The same equivalence was obtained for traction test. In the impact test, the samples with higher fiber proportion have significant higher Izod impact strength, reaching around $58 \mathrm{~J} . \mathrm{m}^{-1}$. The resistance to compression was slightly better for 5 ton compaction. The moisture physical test shows that increasing the fiber content, it increases the moisture. And also at 10 ton the moisture is higher than in 5 ton. Density of the material remains constant independently on the proportion and compaction value.

Comparing the composite material with raw PHW it is possible to verify that the reinforcement with sugar cane fiber, although present visually good appearance, decreases the mechanical resistance and increases moisture and density in the samples. Inserting the fiber content in the PWH makes it harder than the composite. Analyzing the factorial design results the application of 10 ton seems to be inefficient. We suppose that with higher compaction pressure the natural fibers shifts from the interface region decreasing the interaction with the polymeric matrix. With the pressure excess, cracks were formed in the sample decreasing the mechanical properties of the final composite.

Considering the four possibilities of the factorial design, the tests with higher fiber proportion and lower compaction pressure demonstrated the best result. Table 4 present a

Table 3. Factorial Design results for the polymeric composites compared to the mechanical and physical properties of raw PWH. Values and standard deviation for 5 different samples.

\begin{tabular}{|c|c|c|c|c|c|}
\hline Property & Raw PWH & $\begin{array}{c}\text { Composite } 1 \\
70 \% \text { PWH } / 30 \% \text { SCF } \\
5 \text { ton }\end{array}$ & $\begin{array}{c}\text { Composite } 2 \\
60 \% \text { PWH } / 40 \% \text { SCF } \\
5 \text { ton }\end{array}$ & $\begin{array}{c}\text { Composite } 3 \\
70 \% \text { PWH } / 30 \% \text { SCF } \\
10 \text { ton }\end{array}$ & $\begin{array}{c}\text { Composite } 4 \\
60 \% \text { PWH } / 40 \% \text { SCF } \\
10 \text { ton }\end{array}$ \\
\hline $\begin{array}{l}\text { Hardness (Shore D) } \\
(0-100 \text { scale) }\end{array}$ & $41.4 \pm 0.7$ & $51.9 \pm 2.8$ & $52.2 \pm 1.6$ & $51.5 \pm 1.3$ & $48.1 \pm 1.3$ \\
\hline $\begin{array}{l}\text { Flexural strenght } \\
(\mathrm{MPa})\end{array}$ & $18.6 \pm 0.3$ & $16.9 \pm 0.6$ & $18.1 \pm 0.4$ & $15.6 \pm 0.7$ & $14.3 \pm 0.5$ \\
\hline $\begin{array}{l}\text { Tensile resistance } \\
\text { (MPa) }\end{array}$ & $9.6 \pm 0.4$ & $7.5 \pm 0.3$ & $7.6 \pm 0.7$ & $7.5 \pm 0.4$ & $7.9 \pm 0.8$ \\
\hline $\begin{array}{l}\text { Impact resistance } \\
\text { (Izod) }(\mathrm{J} / \mathrm{m})\end{array}$ & $73.9 \pm 2.0$ & $45.6 \pm 1.5$ & $57.5 \pm 4.0$ & $50.5 \pm 4.7$ & $58.0 \pm 2.7$ \\
\hline $\begin{array}{l}\text { Compression strength } \\
(\mathrm{MPa})\end{array}$ & $27.7 \pm 0.9$ & $11.9 \pm 0.8$ & $13.9 \pm 0.5$ & $8.9 \pm 1.2$ & $10.3 \pm 1.8$ \\
\hline Moisture retention (\%) & $0.90 \pm 0.06$ & $1.8 \pm 0.1$ & $2.1 \pm 0.1$ & $1.9 \pm 0.1$ & $2.4 \pm 0.2$ \\
\hline Density $\left(\mathrm{g} \mathrm{cm}^{-3}\right)$ & $1.00 \pm 0.06$ & $1.22 \pm 0.01$ & $1.19 \pm 0.01$ & $1.20 \pm 0.01$ & $1.18 \pm 0.01$ \\
\hline
\end{tabular}

$\mathrm{PWH}=$ Plastic waste from hydrapulper, $\mathrm{SCF}=$ Sugar cane bagasse fiber.

Table 4. Comparison of the optimazed condition reached in this study with literature results.

\begin{tabular}{|c|c|c|c|c|}
\hline Conditions/references & $\begin{array}{c}\text { Tensile } \\
\text { strength } \\
\text { (MPa) }\end{array}$ & $\begin{array}{c}\text { Flexural } \\
\text { strength } \\
(\mathrm{MPa})\end{array}$ & $\begin{array}{c}\text { Izod impact } \\
\text { strength } \\
(\mathrm{J} / \mathrm{m})\end{array}$ & $\begin{array}{c}\text { Compression } \\
\text { strength } \\
\text { (MPa) }\end{array}$ \\
\hline $60 \% \mathrm{PWH} / 40 \%$ sugar cane fiber (our study) & $7.6 \pm 0.7$ & $18.1 \pm 0.4$ & $57.5 \pm 4.0$ & $13.9 \pm 0.5$ \\
\hline $1-80 \%$ Epoxi resin $/ 15 \% \mathrm{FBC} / 5 \%$ glass fiber ${ }^{[13]}$ & 4.69 & $3.96 \pm 0.16$ & $24.01 \pm 0.28$ & 9.60 \\
\hline $2-80 \%$ raw $\mathrm{PEAD} / 20 \%$ sisal fiber ${ }^{[38]}$ & $22.71 \pm 0.10$ & $35.27 \pm 1.02$ & $65.5 \pm 2.37$ & - \\
\hline $2-80 \%$ raw $\mathrm{PP} / 20 \%$ sisal fiber ${ }^{[38]}$ & $28.62 \pm 0.13$ & $49.74 \pm 1.39$ & $34.60 \pm 2.56$ & - \\
\hline $3-50 \%$ recycled $\mathrm{PEAD} / 50 \%$ wheat straw ${ }^{[39]}$ & $8.11 \pm 1.44$ & $13.16 \pm 1.64$ & $47.37 \pm 6.42$ & - \\
\hline $3-50 \%$ recycled $\mathrm{PP} / 50 \%$ wheat straw ${ }^{[39]}$ & $6.42 \pm 1.11$ & $17.76 \pm 1.06$ & $11.06 \pm 1.50$ & - \\
\hline $4-90 \%$ recycled PEAD reciclado $/ 10 \%$ banana fiber ${ }^{[40]}$ & $20.4 \pm 0.3$ & - & $45.2 \pm 1.9$ & - \\
\hline $5-90 \%$ recycled $\mathrm{PEAD} / 10 \%$ sisal fiber ${ }^{[2]}$ & 21.2 & 25.3 & 62.0 & - \\
\hline $6-50 \%$ PSAI $/ 50 \%$ pineapple leaf fiber ${ }^{[41]}$ & $22.64 \pm 1.25$ & $31.66 \pm 3.25$ & $24.39 \pm 1.34$ & - \\
\hline
\end{tabular}

$\mathrm{PWH}=$ plastic waste from hydrapulper; PEHD = polyethylene high-density; PP = Polypropylen; HIPS = high impact polystyrene. 

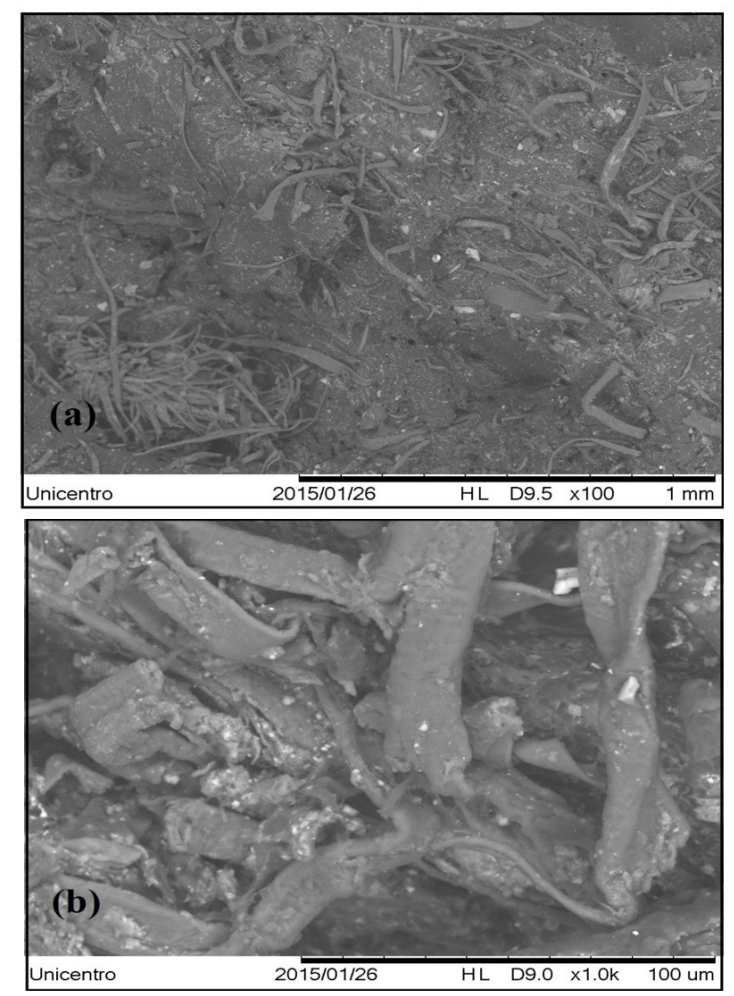

Figure 4. Scanning electron microscopy of the (a) fracture of raw plastic waste from hydrapulper and (b) higher magnification with empty spaces.

comparison with the best result of our study with other similar studies in the literature.

\subsection{Scanning electron microscopy (SEM)}

An image of the fractured surface from the Izod impact sample of raw PWH is presented in Figure 4. It can be noted that there are components that were not melted and kept in the samples as charged particles. The Figure $4 \mathrm{~b}$ highlights the empty spaces between melted and not melted polymers (white points).This indicates the necessity of some kind of reinforcement charge or some coupling agent to increase the interfacial adhesion ${ }^{[22,43]}$.

Thakur et al. have shown that is possible a surface modification, for example, of natural polymers using silane coupling agent ${ }^{[44]}$ or graft copolymerization ${ }^{[45]}$, this change in morphology can causes changes in the properties of the polymers.

Figure $5 \mathrm{a}$ and $\mathrm{b}$ present the micrographs for the composites with $30 \%$ and $40 \%$ of natural fibers. Compared to the micrography of the raw PWH is noted that the reinforcement charge incorporation filled the porous to obtain a more homogeneous material. Figure $5 \mathrm{c}$, with amplification power of 1000 times in the sample with $40 \%$ fiber it still presents several "white dots" related to the polymers not melted, it attests that sugar cane fiber charge was not able to cause an efficient adhesion. However, the final product has interesting properties and applications.
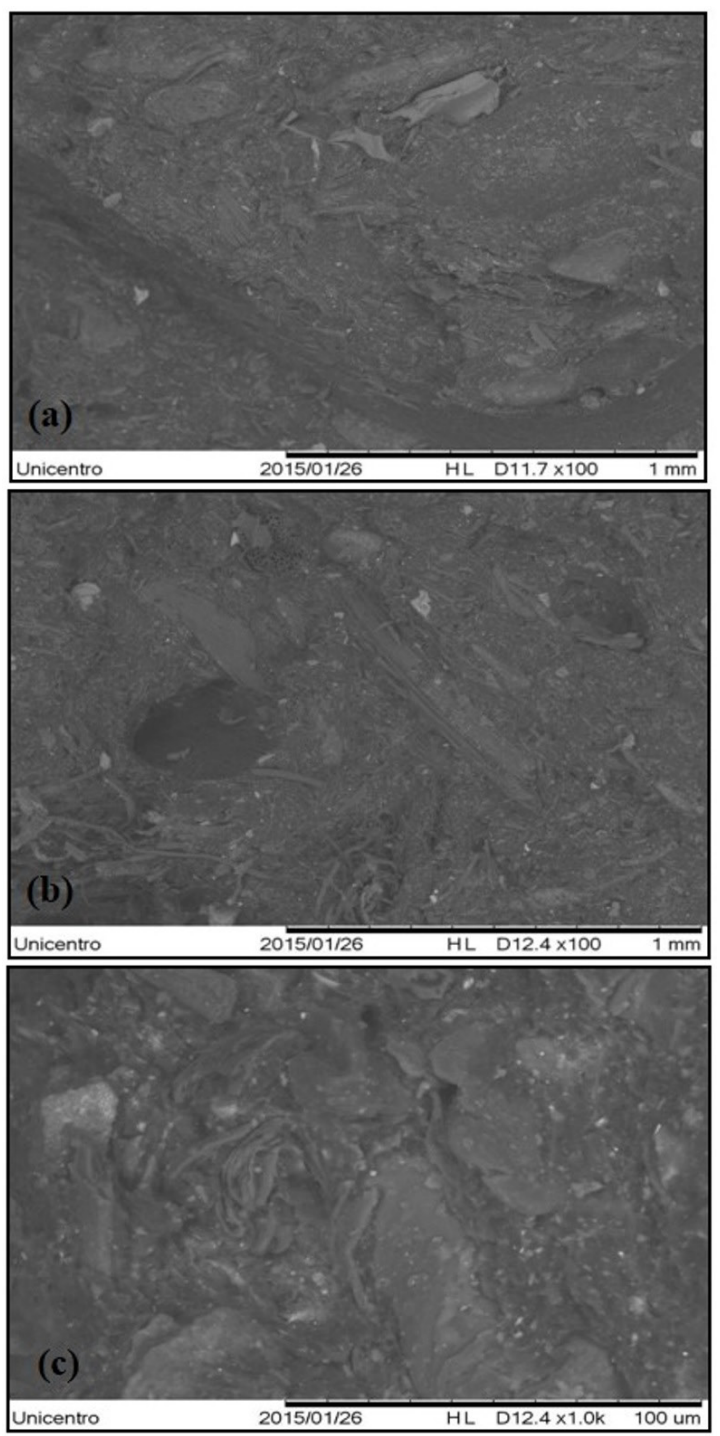

Figure 5. Scanning electron microscopy of the fracture of composites (a) 30\% sugar cane fiber, 100x; (b) 40\% sugar cane fiber, 100x; (c) 40\% sugar cane fiber, 1000x.

\section{Conclusions}

Thermal analysis attested that the composite is resistant up to $250^{\circ} \mathrm{C}$, so it is not degraded in extrusion, injection and thermoset process. The PWH is composed in its majority by polyolefin (PEAD, PP, PEBD) as concluded by DSC analysis.

Compared to the raw $\mathrm{PWH}$, the addition of sugar cane as reinforcement fiber increased the hardness of the material. The other physical and mechanical properties were not improved. Higher fiber proportion in the composite presented positive effects, mainly in the compression and impact tests, although water absorption increased. It was observed that the material presented a woodsy aspect losing its plastic appearance. So, the composite material with $40 \%$ of sugar cane fiber, pressed with 5 ton just after extrusion was the optimized condition reached in this study. Higher 
pressure values caused a decrease in resistance and an increased in moisture.

In the segment of recycled paper and cellulose this study contributes to give a profitable destination to the plastic waste generated as a by-product of recycled paper industry. The polymeric composite produced presents a material with strong environmental appeal as an alternative do wood and some derivatives to be used in buildings and furniture industries.

\section{Acknowledgements}

The authors wish to thank CNPq (National Council of Technological and Scientific Development), CAPES (Coordination for the Improvement of Higher Education Personnel) and MCTI (Ministry of Science, Technology and Innovation), Conv. $\mathrm{n}^{\circ}$ : 01.0010.00/2011.

\section{References}

1. Lopez, J. P., Girones, J., Mendez, J. A., Puig, J., \& Pelach, M. A. (2012). Recycling ability of biodegradable matrices and treis cellulo-reinforced composites in a plastic recycling stream. Journal of Polymers and the Environment, 20(1), 96103. http://dx.doi.org/10.1007/s10924-011-0333-1.

2. Fávaro, S. L., Ganzerli, T. A., Carvalho, A. G. V. No, Silva, O. R. R. F., \& Radovanovic, E. (2010). Chemical, morphological and mechanical analysis of sisal fiber-reinforced recycled highdensity polyethylene composites. Express Polymer Letters, 4(8), 465-473. http://dx.doi.org/10.3144/expresspolymlett.2010.59.

3. Wang, W., Ji, B., Zhang, C., \& Cao, X. (2016). New spin crossover polymeric composite and another way to describe the result. Inorganic Chemistry Communications, 67, 55-59. http://dx.doi.org/10.1016/j.inoche.2016.03.007.

4. Silva, A. L., Silva, L. R. R., Camargo, I. A., Agosttini, D. L. S., Rosa, D. S., Oliveira, D. L. V., Fechine, P. B. A., \& Mazzetto, S. E. (2016). Cardanol-based thermoset plastic reinforced by sponge gourd fibers (Luffa cylindrica). Polímeros: Ciência e Tecnologia, 26, 21-29.

5. Spinacé, M. S., Janeiro, L. G., Bernardino, F. C., \& Grossi, T., \& Paoli, M. A. (2011). Poliolefinas reforçadas com fibras vegetais curtas: sisal × curauá. Polímeros: Ciência e Tecnologia, 21(3), 168-174.

6. Karakus, K., Birbilen, Y., \& Mengeloğlu, F. (2016). Assessment of selected properties of LDPE composites reinforced with sugar beet pulp. Measurement, 88, 137-146. http://dx.doi. org/10.1016/j.measurement.2016.03.039.

7. El-Fattah, A. A., Demerdash, A. G. M., Alim Sadik, W. A., \& Bedir, A. (2015). The effect of sugarcane bagasse fiber on the properties of recycled high density polyethylene. Journal of Composite Materials, 49(26), 3251-3262. http://dx.doi. org/10.1177/0021998314561484.

8. Taflick, T., Maich, E. G., Ferreira, L. D., Bica, C. I. D., Rodrigues, S. R. S., \& Nachtigall, S. M. B. (2015). Acacia bark residues as filler in polypropylene composites. Polímeros: Ciência e Tecnologia, 25, 289-295. http://dx.doi.org/10.1590/01041428.1840.

9. Martins, R. R., Pires, A. T. N., Al-Qureshi, H. A., \& Barra, G. M. O. (2008). Estudo da viabilidade de utilização de fibras naturais curtas em matrizes de resina epóxi. Matéria (Rio de Janeiro), 13(4), 605-610. http://dx.doi.org/10.1590/S151770762008000400005 .

10. Rzatki, F. D., \& Barra, G. M. O. (2014). Efeito da modificação de superfície de fibras nas propriedades mecânicas de compósitos a base de poli(tereftalato de butileno) reforçado por fibras naturais inorgânicas. Polimeros: Ciência e Tecnologia, 24(3), 344-350.

11. Thakur, V. K., \& Thakur, M. K. (2014). Processing and characterization of natural celulose fibers/thermoset polymer composites. Carbohydrate Polymers, 109, 102-117. PMid:24815407. http://dx.doi.org/10.1016/j.carbpol.2014.03.039.

12. Ali, M., Liu, A., Sou, H., \& Chouw, N. (2012). Mechanical and dynamic properties of coconut fibre reinforced concrete. Construction \& Building Materials, 30, 814-825. http://dx.doi. org/10.1016/j.conbuildmat.2011.12.068.

13. Araujo, J. R., Adamo, C. B., Costa e Silva, M. V., \& De Paoli, M.-A. (2013). Antistatic-reinforced biocomposites of polyamide- 6 and polyaniline-coated curauá fibers prepared on a pilot plant scale. Polymer Composites, 34(7), 1081-1090. http://dx.doi.org/10.1002/pc.22516.

14. Siregar, J. P., Sapuan, S. M., Rahman, M. Z. A., \& Zaman, H. M. D. K. (2010). The effect of alkali treatment on the mechanical properties of short pineapple leaf fibre (PALF) reinforced high impact polystyrene (HIPS) composites. Journal of Food, Agriculture \& Environment, 8(2), 1103-1108.

15. Mattos, B. D., Misso, A. L., Cademartori, P. H. G., Lima, E. A., Magalhães, W. L. E., \& Gatto, D. A. (2014). Properties of polypropylene composites filled with a mixture of household waste of mate-tea and wood particles. Construction \& Building Materials, 61, 60-68. http://dx.doi.org/10.1016/j. conbuildmat.2014.02.022.

16. Saba, N., Jawaid, M., Alothman, O. Y., \& Paridah, M. T. (2016). A review on dynamic mechanical properties of natural fibre reinforced polymer composites. Construction \& Building Materials, 106, 149-159. http://dx.doi.org/10.1016/j. conbuildmat.2015.12.075.

17. Khorami, M., \& Ganjian, E. (2011). Comparing flexural behaviour of fibre-cement composites reinforced bagasse: wheat and eucalyptus. Construction \& Building Materials, 25(9), 36613667. http://dx.doi.org/10.1016/j.conbuildmat.2011.03.052.

18. Tewari, M., Singh, V. K., Gope, P. C., \& Chaudhary, A. K. (2012). Evaluation of mechanical properties of bagasseglass fiber reinforced composite. Journal of Materials and Environmental Science, 3, 171-184.

19. Moubarik, A., Grimi, N., \& Boussetta, N. (2013). Structural and thermal characterization of Moroccan sugar cane bagasse cellulose fibers and their applications as a reinforcing agent in low density polyethylene. Composites. Part B, Engineering, 52, 233-238. http://dx.doi.org/10.1016/j.compositesb.2013.04.040.

20. Jacobsen, S. E., \& Wyman, C. E. (2002). Xylose monomer and oligomer yields for uncatalyzed hydrolysis of sugarcane bagasse hemicelluloses at varying solids concentration. Industrial \& Engineering Chemistry Research, 41(6), 1454-1461. http:// dx.doi.org/10.1021/ie001025+.

21. Bruns, R., Scarminio, I. S., \& Barros, B. B., No. (2006) Statistical design - chemometrics (Vol. 25). Amsterdam: Elsevier. (Data Handling in Science and Technology).

22. Heikkinen, J. M., Hordijik, J. C., Jong, W., \& Spliethoff, H. (2004). Thermogravimetry as a tool to classify waste components to be used for energy generation. Journal of Analytical and Applied Pyrolysis, 71(2), 883-900. http://dx.doi.org/10.1016/j. jaap.2003.12.001.

23. Velásquez, J., Valencia, S., Rios, L., Restrepo, G., \& Marín, J. (2012). Characterization and photocatalytic evaluation of polypropylene and polyethylene pellets coated with $\mathrm{P}_{2} 5 \mathrm{TiO}_{2}$ using the controlledtemperature embedding method. Chemical Engineering Journal, 203,398-405. http://dx.doi.org/10.1016/j. cej.2012.07.068

24. Sardot, T., Smith, G., \& McDonald, A. G. (2012). Valorizing mixed plastic waste from cardboard recycling by amendment 
with wood, cement and ash. Journal of Reinforced Plastics and Composites, 31(21), 1488-1497. http://dx.doi. org/10.1177/0731684412459984.

25. Hatakeyama, T., \& Quinn, F. X. (1999). Thermal analysis: fundamentals and applications to polymer science. Tokyo: Chichester J. Wiley.

26. Santos, M. L., Lima, O. J., Nassar, E. J., Ciuffi, K. J., \& Calefi, O. S. (2011). Estudo das condições de estocagem do bagaço de cana-de-açúcar por análise térmica. Quimica Nova, 34(3), 507-511. http://dx.doi.org/10.1590/S0100-40422011000300024.

27. Caraschi, J. C., \& Leão, A. L. (2002). Avaliação das propriedades mecânicas dos plásticos reciclados provenientes de resíduos sólidos urbanos. Acta Scientiarum, 24(6), 1599-1602.

28. Coutinho, F. M. B., Mello, I. L., \& Santa Maria, L. C. (2003). Polietileno: principais tipos, propriedades e aplicações. Polímeros: Ciência e Tecnologia, 13(1), 1-3.

29. Milagres, E. G., Vital, B. R., Della, L. R. M., \& Pimenta, A. S. (2006). Compósitos de partículas de madeira de Eucalyptus grandis, polipropileno e polietileno de alta e baixa densidades. Revista Árvore, 30(3), 463-470. http://dx.doi.org/10.1590/ S0100-67622006000300017.

30. Hillig, E., Freire, E., Carvalho, G. A., Schneider, V. E., \& Pocai, K. (2006). Moldagem de misturas na fabricação de compósitos polímero-fibra utilizando polietileno e serragem de pinus sp. Ciência Florestal, 16(3), 343-351. http://dx.doi. org/10.5902/198050981913.

31. Runzhou, H., Xinwu, X., Sunyoung, L., Yang, Z., BirmJune, K., \& Qinglin, W. (2013). High Density Polyethylene composites reinforced with hybrid inorganic fillers: morphology, mechanical and thermal expansion performance. Matéria (Rio de Janeiro), 6(9), 4122-4138. http://dx.doi.org/10.3390/ ma6094122. PMid:28788322.

32. Rosário, F., Pachekoski, W. M., Silveira, A. P. J., Santos, S. F., Júnior, H. S., \& Casarin, S. A. (2011). Resíduos de sisal como reforço em compósitos de polipropileno virgem e reciclado. Polímeros: Ciência e Tecnologia, 21(2), 90-97. http://dx.doi. org/10.1590/S0104-14282011005000021.

33. Bodzay, B., Fejos, M., Bocz, K., Told, A., Ronkay, F., \& Marosi, G. (2012). Upgrading of recycled polypropylene by preparing flame retarded layered composite. Express Polymer Letters Journal, 6(11), 895-902. http://dx.doi.org/10.3144/ expresspolymlett.2012.95.

34. Becker, D., Balzer, A. K. P., \& Soldi, V. (2011). Influência da sequência de mistura do PP-MA nas propriedades dos compósitos de PP e fibra de bananeira. Polímeros: Ciência e Tecnologia, 21(1), 7-12. http://dx.doi.org/10.1590/S010414282011005000012.

35. Vick. (2016). Polipropileno. Retrieved in 2016, January 15, from http://www.vick.com.br/vick/novo/datasheets/datasheetpolipropileno-pp-nit.pdf
36. Mahendrasinh, M. R., Hemul, V. P., Lata, M. R., \& Naynika, K. P. (2013). Studies on mechanical properties of recycled polypropylene blended with virgin polypropylene. International Journal of Zoological Research, 2(3), 194-203.

37. Strapasson, R., Amico, S. C., Pereira, M. F. R., \& Sydenstricker, T. H. D. (2005). Tensile and impact behavior of polypropylene/ low density polyethylene blends. Polymer Testing, 24(4), 468473. http://dx.doi.org/10.1016/j.polymertesting.2005.01.001.

38. Spinacé, M. A. S., Janeiro, L. G., Bernardino, F. C., Grossi, T. A. \& De Paoli, M. A. (2011). Poliolefinas reforçadas com fibras vegetais curtas: Sisal Vs. Curauá. Polímeros: Ciência e Tecnologia, 21(3), 168-174.

39. Mengeloglu, F., \& Karakus, K. (2008). Thermal degradation mechanical properties and morphology of wheat straw flour filled recycled thermoplastic composites. Sensors (Basel), 8(1), 500-519. http://dx.doi.org/10.3390/s8010500. PMid:27879719.

40. Albinante, S. R., Pacheco, E., Visconte, L., Platenik, G., Batista, L. N. (2014). Modification of brazilian natural fibers from banana's tree to apply as fillers into polymers composites. Chemical Engineering Transactions, 37, 715-720. http://dx.doi. org/10.3303/cet1437120.

41. Siregar, J. P., Sapuan, S. M., Rahman, M. Z. A., \& Zaman, H. M. D. K. (2010). The effect of alkali treatment on the mechanical properties of short pineapple leaf fibre (PALF) reinforced high impact polystyrene (HIPS) composites. Journal of Food Agriculture and Environment, 8, 1103-1108.

42. Li, X., Lei, B., Lin, Z., Huang, L., Tan, S., \& Cai, X. (2014). The utilization of bamboo charcoal enhances wood plastic composites with excelent mechanical and termal properties. Materials \& Design, 53, 419-424. http://dx.doi.org/10.1016/j. matdes.2013.07.028

43. Yeh, S. K., Kim, K. J., \& Gupta, R. K. (2012). Synergistic effect of coupling agents on polypropylene-based woodplastic composites. Journal of Applied Polymer Science, 27, 1047-1053. http://dx.doi.org/10.1002/app.37775.

44. Thakur, M. K., Gupta, R. K., \& Thakur, V. K. (2014). Surface modification of cellulose using silane coupling agent. Carbohydrate Polymers, 111, 849-855. PMid:25037424. http:// dx.doi.org/10.1016/j.carbpol.2014.05.041.

45. Thakur, V. K., Singha, A. S., \& Thakur, M. K. (2012). Surface modification of natural polymers to impart low water absorbency. International Journal of Polymer Analysis and Characterization, 17(2), 133-143. http://dx.doi.org/10.1080 /1023666X.2012.640455.

Received: Jan. 19, 2017

Revised: May 18, 2017

Accepted: June 14, 2017 